\title{
TORPOR AND OTHER PHYSIOLOGICAL ADAPTATIONS OF THE BADGER (TAXIDEA TAXUS) TO COLD ENVIRONMENTS ${ }^{1}$
}

\begin{abstract}
HENRY J. HARLOW
Department of Zoology and Physiology, University of Wyoming, Laramie, Wyoming 82071

(Accepted 4/21/80)

Oxygen consumption $\left(\dot{\mathrm{V}}_{2}\right)$ and heart rate were measured at ambient temperatures between +20 and $-40 \mathrm{C}$. Basal metabolic rate was $0.3 \mathrm{~cm}^{3} / \mathrm{g} \cdot \mathrm{h}$ ( 65 beats $/ \mathrm{min}$ ), the body temperature was $38 \mathrm{C}$, the lower critical temperature $\left(T_{l c}\right)$ was $10 \mathrm{C}$, and conductance was $0.01225 \mathrm{~cm}^{3} / \mathrm{g} \cdot \mathrm{h}^{\circ} \mathrm{C}$. Fat composition of 79 adult badgers captured during the winter showed maximal fat deposition of $31 \%$ body weight in November. Fat stores were reduced $37 \%$ between November and March. The burrow temperature remained between 0 and $4 \mathrm{C}$ throughout the winter. Badgers in outdoor enclosures during the winter of 1977-1978 reduced their above-ground exposure by 93\% from November through February. Two badgers remained below ground for more than 70 consecutive days during the 1978-1979 winter. While below ground, one telemetered badger entered a state of torpor, on 30 occasions, characterized by a $50 \%$ reduction in heart rate (from 55 to 25 beats $/ \mathrm{min}$ ) and a $9 \mathrm{C}$ reduction in body temperature (from 38 to $29 \mathrm{C}$ ). The torpor cycle lasted an average of $29 \mathrm{~h}$ (entrance$15 \mathrm{~h}$, torpor- $-8 \mathrm{~h}$, arousal- $6 \mathrm{~h}$ ). Each cycle provided a $27 \%$ or $81 \mathrm{kcal} /$ cycle reduction in energy expenditure.
\end{abstract}

\section{INTRODUCTION}

Many temperate-zone mammals exhibit both behavioral and physiological adaptations to cold. One of the most effective behavioral mechanisms is to avoid extreme cold through the use of a burrow or den (Pruitt 1960; Vose and Dunlap 1968; Stephenson 1969; Brocke 1970). Reliance on a fossorial shelter may be reflected in an animal's quality of thermal insulation, its ability to lower its metabolic requirements through hypothermia, and its dependence upon fat storage during winter.

${ }^{1}$ I am greatly indebted to Dr. Harold Bergman, Dr. Jack Turner, Richard Guenzel, and Maryanne Harlow for their support during the course of these investigations. In addition, I would like to acknowledge Drs. Francis Long and Richard Weeks from the University of Wyoming for developing the micro-hybrid circuit telemetry systems used in this study. This research was supported by a University of Wyoming basic research grant and by National Science Foundation grant DEB 76-21414. This paper is extracted from a dissertation at the University of Wyoming in partial fulfillment of the requirements for the Ph.D. degree.

Physiol. Zool. 54(3):267-275. 1981.

(c) 1981 by The University of Chicago. 0031-935X/ $81 / 5403-7977 \$ 02.00$
The badger, Taxidea taxus, is a semifossorial mammal that remains below the ground for extended periods during midwinter in response to cold (Harlow 1979a). $\mathrm{McNab}$ (1966) reported that fossorial rodents tend to have higher conductance (the reciprocal of insulation) than predicted by standard formulas. This same characteristic may be reflected by the badger. A high thermal conductance may restrict the badger's exposure to cold and consequent predatory activity during the winter, causing an increased reliance on fat reserves. In addition, the badger is an opportunistic feeder which relies primarily on small mammals, which may be more difficult to obtain during the winter (Lampe 1976). Badgers which are restricted to a winter den because of food shortage and cold may, therefore, have to reduce their energy requirements for activity and maintenance of body temperature (Mrosovsky 1976) in order to conserve fat stores.

Morrison (1960) stated that fat reserves in mammals within the size range of badgers would not be sufficient to sustain these animals over a winter season without a 
substantial reduction in metabolism. However, he also suggested that there is little need for extensive hypothermia in mammals of this size because of their relatively large body mass and fat reserves. Bears, Ursus sp. (Nelson 1973; Folk 1974), the opossum, Didelphis marsupialis (Brocke 1970), and the European badger, Meles meles (Slonin 1952; Johansson 1957) are known to exhibit signs of torpor. It is possible that the American badger also has the ability to lower its body temperature and metabolic requirements during the winter while beneath the ground and thereby conserve energy.

It is, therefore, the purpose of this study to investigate the badger's (1) winter activity and behavioral avoidance of cold temperatures, (2) thermal insulation, (3) seasonal fat utilization, and (4) energy requirements during the winter in order to understand the badger's adaptations to conditions of cold and food scarcity.

\section{MATERIAL AND METHODS}

EXPERIMENTAL ANIMALS

Badgers were collected in Albany County, Wyoming, during the summers of 1977 and 1978 and maintained either in outdoor enclosures or in rooms exposed to outside temperature and photoperiod. Only female badgers weighing between 7.5 and $9.5 \mathrm{~kg}$ were used in this study. They were fed Purina Dog Chow consisting of $21 \%, 8 \%$, and $4.5 \%$ crude protein, fat, and fiber, respectively, and with a gross energy content of $5.15 \mathrm{kcal} / \mathrm{g}$.

METABOLIC RESPONSE TO COLD TEMPERATURES

Oxygen consumption $\left(\dot{\mathrm{V}}_{\mathrm{O}_{2}}\right)$ on six badgers was derived from the changes in composition of a measured flow of air through a 50liter respirometer. Rate of flow was measured with a Datametrics model $800-\mathrm{L}$ hot wire anemometer and maintained at 6 liters/min. A portion of this air, scrubbed of $\mathrm{CO}_{2}$ and water, was measured for oxygen content with a Beckman M-3 paramagnetic oxygen analyzer, and $\dot{\mathrm{V}}_{\mathrm{O}_{2}}$ was calculated from formula number 10 of Depocas and Hart (1957). Oxygen consumption was determined between 1600 and 2200 MST at $10 \mathrm{C}$ increments between +20 and -40 $\mathrm{C}$ on animals previously fasted for $16 \mathrm{~h}$. The lower critical temperature $\left(T_{l c}\right)$ was determined by the method of Welch (1978) from the intersection of regression lines representing $\dot{\mathrm{V}}_{\mathrm{O}_{2}}$ at different ambient temperatures. Thermal conductance was obtained from the slope of the regression line representing $\dot{\mathrm{V}}_{\mathrm{O}_{2}}$ at temperatures below the $T_{l c}$.

\section{SEASONAL FAT MEASUREMENTS}

Animal carcasses were collected during 1977-1978 from a local furrier and as road kills. Animals were sexed and the upper canine tooth removed for age determination by the cemental annuli technique (Crow 1972). Total body fat was determined for 79 adult badgers by specific gravity analysis (Brocke 1970). Animals were skinned and viscera removed, with the exception of genital organs, kidneys, and associated fat. The carcass was weighed in air to within $0.1 \mathrm{~g}$ and again while submerged in water with added detergent. From these weights, the specific gravity (SG) of each carcass was determined and $\%$ fat calculated from the formula: $\%$ fat $=100-(4.56 / \mathrm{SG})-$ 4.0. This assumes a density for fat tissue of 0.912 (Morales et al. 1945), and for lean tissue of 1.12, based on the lowest densities of badger carcasses (see Brocke 1970). Values obtained by this method were within $5 \%$ of those obtained from a chloroform/ methanol extraction of whole carcasses.

The right femur was removed from each carcass, weighed to $0.001 \mathrm{~g}$, and broken into shards. The shards were placed into a $30-\mathrm{ml}$ Teflon centrifuge tube which contained a grid platform constructed so that the shards were supported over $5 \mathrm{ml}$ of a chloroform/ methanol $(2: 1)$ solution. When the shards were spun at $800 \times g$ for $15 \mathrm{~min}$, virtually all marrow fat was removed from the femur and dissolved in the solution. Fat content of the bone marrow was then determined by evaporating the chloroform/methanol solution and weighing the fat residue to $0.001 \mathrm{~g}$. 
HEART RATE AND BODY TEMPERATURE MEASUREMENT

Telemetry transmitters for heart rate and body temperature were developed (Weeks et al. 1978) and surgically implanted into the peritoneal cavities of badgers during the winter of 1977-1978 and again in the winter of 1978-1979. Stainless-steel electrocardiogram (EKG) electrodes leading from the transmitters were implanted $2 \mathrm{~cm}$ on either side of the sternum. Heart rate and $\dot{\mathrm{V}}_{\mathrm{O}_{2}}$ of badgers were determined simultaneously in the laboratory by using varying ambient temperatures to promote significant changes in metabolism (Holter et al. 1976). Telemetered animals weighing an average of $8 \mathrm{~kg}$ were released into separate outdoor enclosures made of cyclone fencing measuring $5 \mathrm{~m}$ on a side and extending $2 \mathrm{~m}$ beneath the ground with an enclosed bottom. Heart rate and body temperature signals transmitted from badgers within each enclosure were picked up by a ferrite rod antenna within polyvinylchloride (PVC) tubing buried $1 \mathrm{~m}$ below ground. Signals were processed by a digital/ analog ratemeter (Harlow et al. 1979) and continuously recorded on an Esterline Angus model 402 multichannel recorder located in an insulated building $15 \mathrm{~m}$ from the enclosure.

BURROW TEMPERATURE AND BURROW USE

The temperature $6 \mathrm{~cm}$ above the ground and within two burrows was monitored continuously during the winter of 19771978 with a Dickerson 7-day Minicorder, model 42-2. To monitor burrow temperature, thermocouple probes from the recorder were pushed through the dirt plugging the entrance and as far into the burrow as possible.

The length of time each badger spent in its burrow was determined with a directional photocell monitoring system placed at the burrow entrance (Harlow 1979b).

A Student $t$-test and least-squares regression were employed to examine differences between means and linear correlation of data, respectively (Neter and Wasserman 1974).

\section{RESULTS}

Basal metabolic rate (BMR) for badgers weighing an average of $9.0 \mathrm{~kg}$ was 0.3 $\mathrm{cm}^{3} / \mathrm{g} \cdot \mathrm{h}$ or $311 \mathrm{kcal} /$ day, $14 \%$ below the $363 \mathrm{kcal} /$ day value predicted from the equation $M=70 W^{\mathbf{0 . 7 5}}$ (Kleiber 1975). The lower critical temperature $\left(T_{l c}\right)$ was $10 \mathrm{C}$, while conductance was calculated as 0.01225 $\mathrm{cm}^{3} / \mathrm{g} / \mathrm{h} /{ }^{\circ} \mathrm{C}$ (fig. 1).

Body weight and lipid fraction of adult badgers increased during the summer and fall and peaked in November with an average weight of $8.05 \mathrm{~kg}$ and lipid fraction of $31 \%$ (figs. 2 and 3 ). Body weight and fat stores of animals in this population were reduced $15 \%$ and $37 \%$, respectively, between November and March. Deposition of fat into bone marrow increased in these animals from August through February with no significant decline through March (fig. 4).

Burrow temperatures during the winter 1977-1978 remained between 0 and $4 \mathrm{C}$, while average weekly, above-ground minimum temperatures were between -5 and $-15 \mathrm{C}$ (fig. 5). Badgers in field enclosures

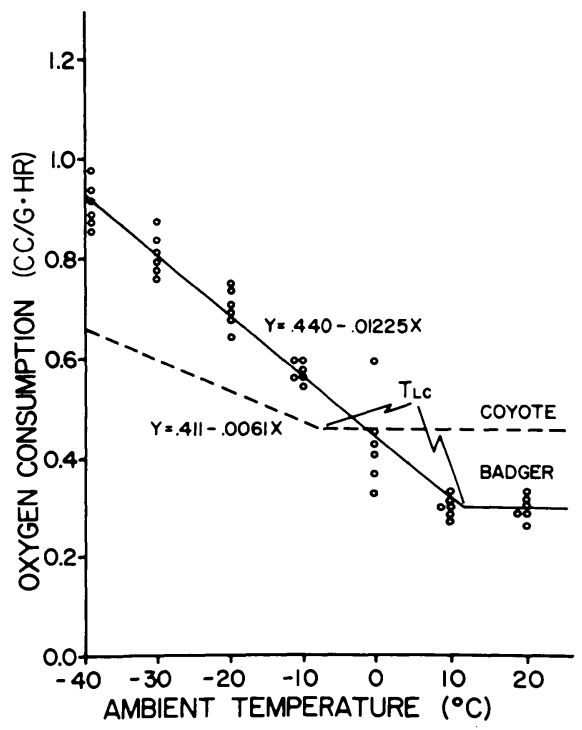

FIG. 1.-Oxygen consumption of six badgers and three coyotes described by least-squares regression over ambient temperatures between +20 and $-40 \mathrm{C}$. The lines representing the coyote were constructed from data reported by Shield (1972). 


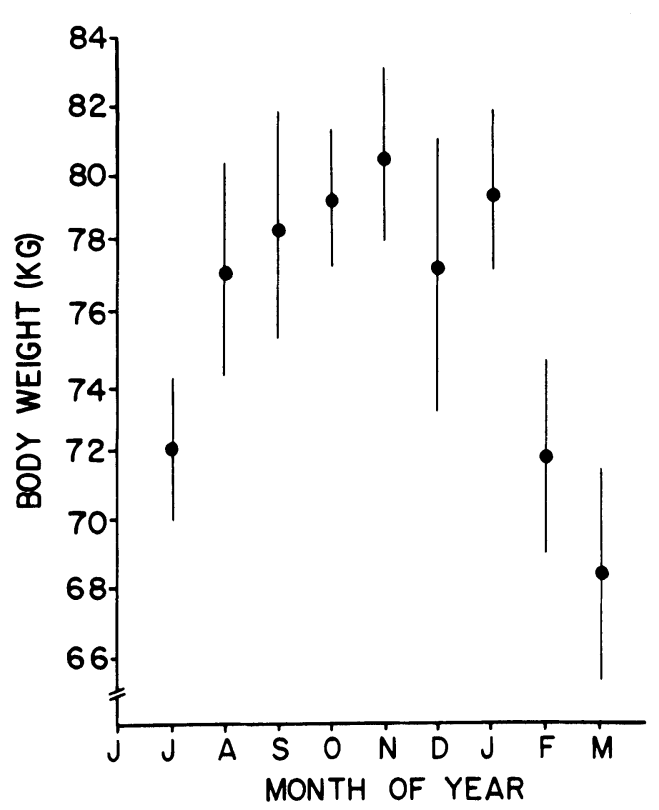

Fig. 2.-Seasonal changes in body weight for 79 adult badgers; closed circles represent means, vertical lines represent $\pm 2 \mathrm{SE}$.

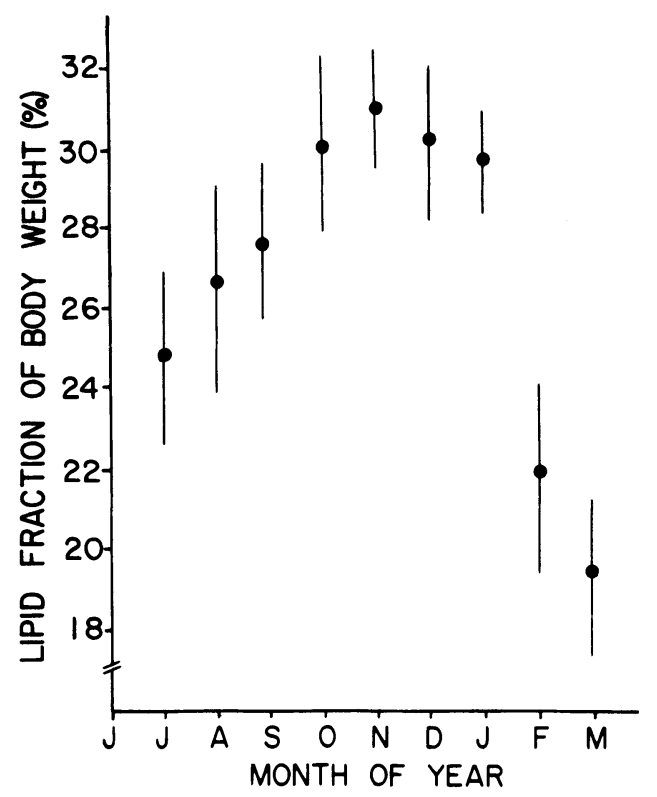

Fig. 3.-Seasonal changes in body fat of 79 adult badgers; closed circles represent means, vertical lines represent $\pm 2 \mathrm{SE}$. during the winter of 1977-1978 reduced their above-ground activity by $93 \%$ from November through February. This was followed by a $220 \%$ increase in aboveground nocturnal activity by April, when temperatures were warmer (fig. 6). The 1978-1979 winter had ambient temperatures of about $10 \mathrm{C}$ lower than the previous year. Two badgers monitored January through March remained below ground for 74 and 85 continuous days.

Heart rate of badgers was significantly $(r=.97)$ correlated with oxygen consumption (fig. 7). The heart rate of badgers while below ground during February and March 1978 was about 65 beats/min (figs. 8 and 9), which corresponds to a metabolic rate of $0.32 \mathrm{~cm}^{3} / \mathrm{g} \cdot \mathrm{h}$. Above-ground behavior consisted of foraging, feeding, and digging activities. During February, badgers were active above ground between 1500 and 0100 MST and had an average heart rate of 90 beats $/$ min $(0.42 \mathrm{~cm} / \mathrm{g} \cdot \mathrm{h})$ (fig. 8). During March, badgers engaged in above-ground

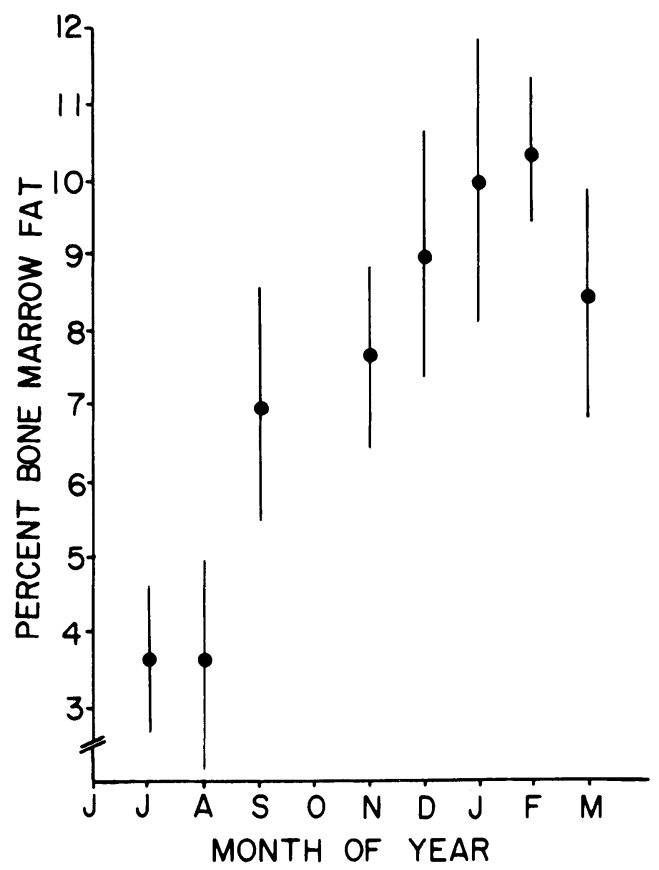

Fig. 4.-Seasonal changes in bone marrow fat for 79 adult badgers; closed circles represent means, vertical lines represent $\pm 1 \mathrm{SE}$. 
activity over a greater number of hours per day (1600-0600 MST) with an average heart rate of 150 beats $/ \min \left(0.96 \mathrm{~cm}^{3} / \mathrm{g} \cdot \mathrm{h}\right)$ (fig. 9). During the winter 1978-1979, continuous telemetry signals were received for only one of the two badgers remaining constantly below ground. During this time, the heart rate was only occasionally elevated above 55 beats $/ \min \left(0.27 \mathrm{~cm}^{3} / \mathrm{g} \cdot \mathrm{h}\right)$. In addition, on 30 occasions the badger entered torpor which was characterized by a drop of $9 \mathrm{C}$ in body temperature and a $50 \%$ reduction in heart rate (fig. 10). Entrance into hypothermia was gradual, taking about $15 \mathrm{~h}$ at $0.55 \mathrm{C} \mathrm{drop/h}$. Torpor, characterized by a body temperature of approximately $28 \mathrm{C}$ and a heart rate of 21-30 beats/min, persisted an average of 8 h. Arousal was characterized by an almost simultaneous elevation of the heart rate and body temperature. Warming of the body was more rapid than cooling, taking only about $4 \mathrm{~h}$ at a rate of $2.22 \mathrm{C} / \mathrm{h}$. The average cycle of torpor lasted $29 \mathrm{~h}$ from the

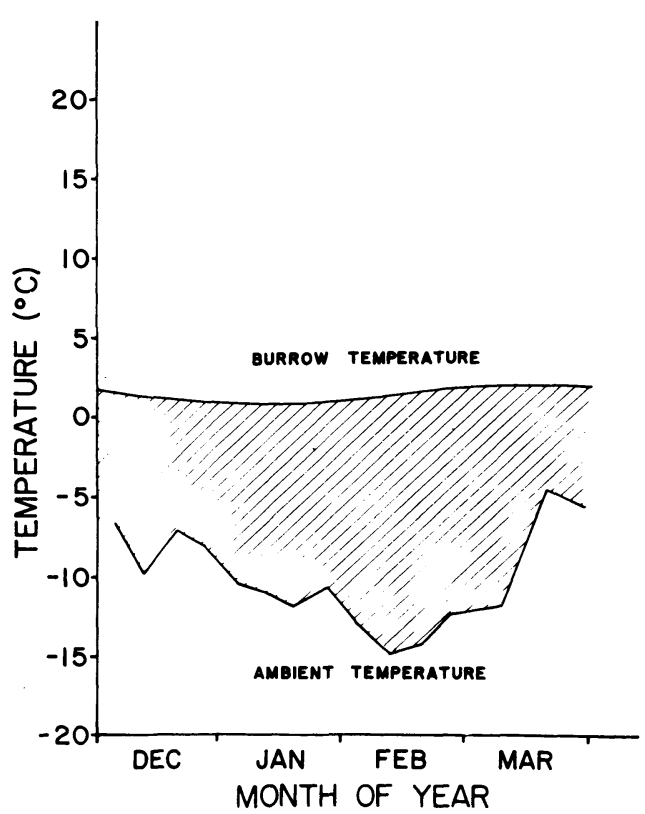

Fig. 5.-Average burrow temperatures and average minimum weekly above-ground temperatures, December through March 1977-1978; temperatures were measured $1.5 \mathrm{~m}$ within and $6 \mathrm{~cm}$ above the entrance of two burrows. initial reduction in heart rate to the end of arousal (defined as the return to a resting heart rate of 55 beats $/ \mathrm{min}$ ).

\section{DISCUSSION}

Conductance is an exponential function of body weight and can therefore be predicted from the general formula: $C=1.02$ $W^{-0.505}$ (Herreid and Kessel 1967). The observed value of $0.01225 \mathrm{~cm}^{3} / \mathrm{g} / \mathrm{h} /{ }^{\circ} \mathrm{C}$ was $16 \%$ higher than the predicted value of $0.01027 \mathrm{~cm}^{3} \mathrm{~g} / \mathrm{h} /{ }^{\circ} \mathrm{C}$ for a $9.0 \mathrm{~kg}$ animal. Gettinger (1975) found low values of conductance for fossorial animals and expressed this as an adaptation for preventing excessive heat loss. McNab (1966), however, characterized fossorial rodents as having high conductance as a means of limiting the heat load incurred during active digging. It is difficult to explain the high conductance values observed for the temperatezone badger during winter in terms of the need to dissipate heat, but it may indeed be

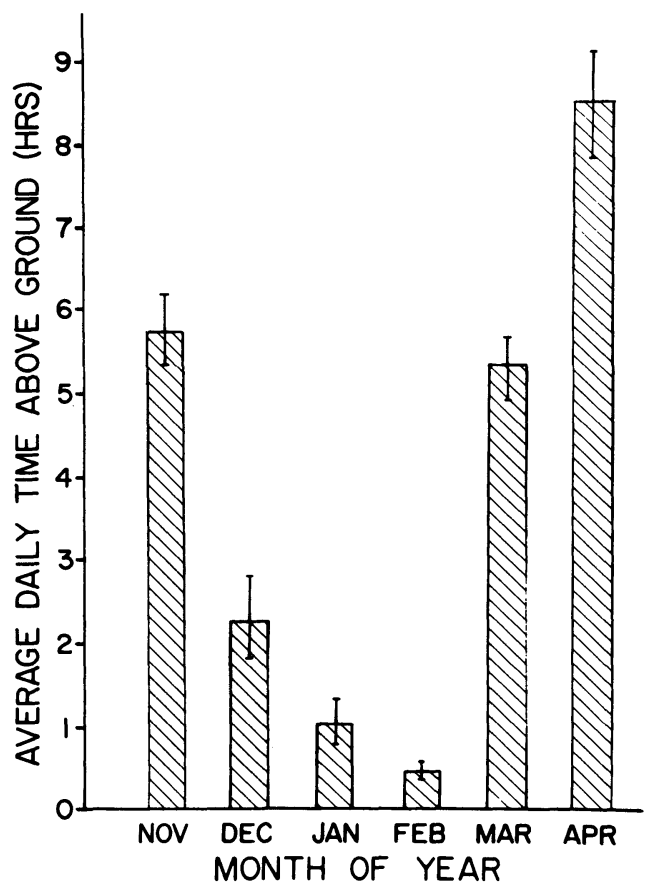

FIg. 6.-Average daily time above ground for four adult badgers within outdoor enclosures, November 1977 through April 1978; brackets represent $\pm 1 \mathrm{SE}$. 


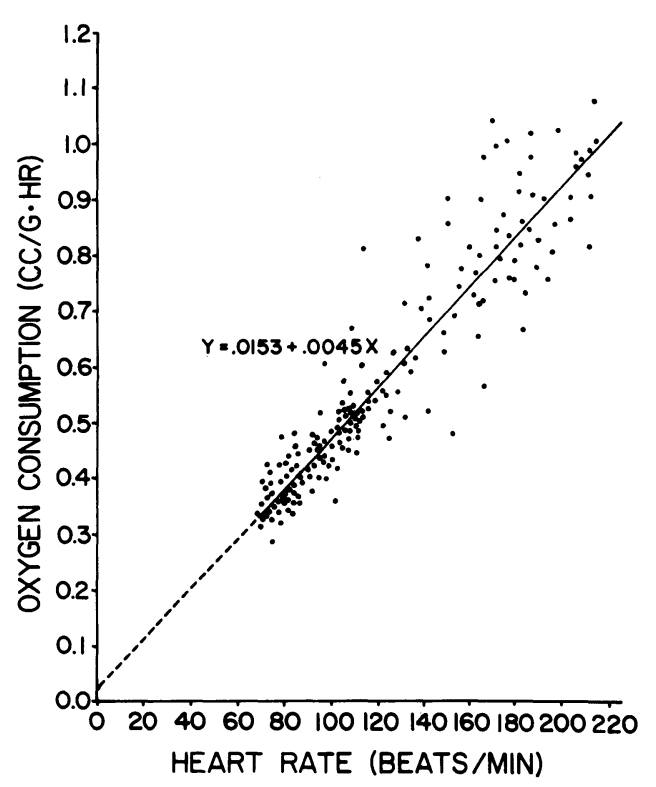

FIG. 7.-Least-squares regression line of heart rate and oxygen consumption for two badgers at rest and at different stages of activity.

associated with the thermal buffering effect of the burrow. The coyote, Canis latrans, is generally nonfossorial and, as a result, is exposed to cold temperatures for longer periods than the badger during the winter. Insulation of the badger is significantly lower $\left(P<.005 ; F^{*}\right.$-statistic of error sum of squares [SSE] [Neter and Wasserman 1974, p. 163]) than insulation calculated from data presented by Shield (1972) on coyotes similarly tested (fig. 1). Conditions associated with burrows (see Swan 1974) could reduce winter thermal stress to the badger and therefore be correlated with a higher thermal conductance (lower insulation).

The BMR of badgers is $30 \%$ below that predicted by Iverson's (1972) equation for mustelids and $14 \%$ below that predicted by Kleiber's (1975) equation for an animal of its body mass. The low rate of metabolism could be associated with problems of balancing an energy budget with limited energy reserves (McNab 1966). For example, squirrels, which reduce their energy requirements by hibernating, deplete only about
$66 \%$ of their fat reserves through the winter (Fisher and Manery 1967). Badgers likewise deplete only about half of their fat stores during winter. In addition, bone marrow fat, which is used as an indicator of an animal's condition (Cheatum 1949; Franzmann and Arneson 1976), showed no significant depletion by March, indicating that badgers still had adequate fat reserves. These large fat deposits at the end of winter may be a result of low energy requirements caused by the badger's behavioral avoidance of cold temperatures and its low metabolic rate.

In the present study, oxygen consumption and heart rate were highly correlated, and the curve fell midway between those obtained by Lampe (1976) from two female badgers on a treadmill. Heart rate was therefore used to estimate metabolic ex-

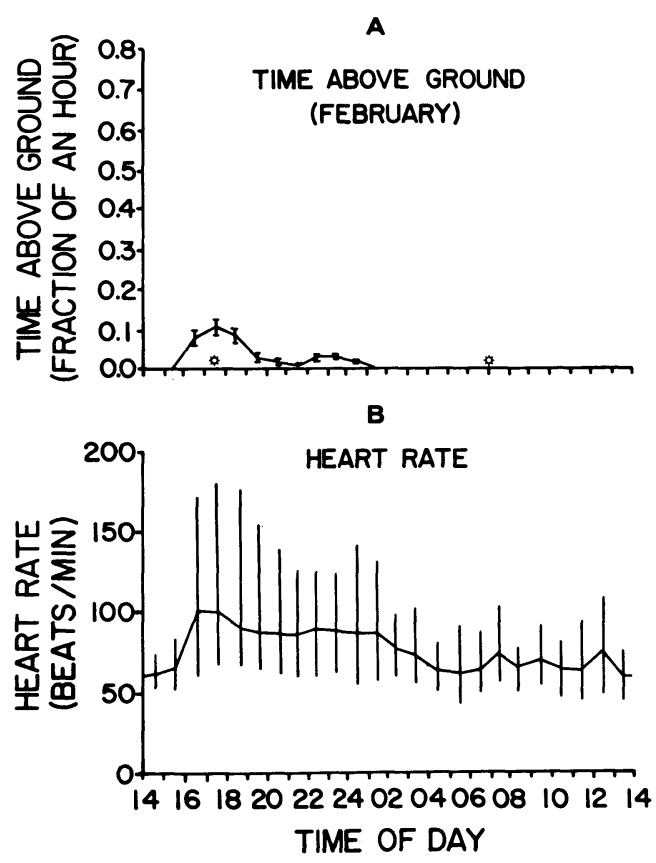

FIG. 8.-Changes in the time spent above ground $(A)$ and changes in heart rate $(B)$ by badgers during February 1978. Time spent above ground for four badgers is expressed in fractions of an hour and represents hourly values averaged for the month; brackets represent $\pm 1 \mathrm{SE}$. Symbols represent sunrise and sunset. Heart rate of two badgers is expressed as the monthly average over 1-h periods; vertical lines represent the range. 
penditures of badgers monitored in field enclosures. By correlating heart rate to $\dot{\mathrm{V}}_{\mathrm{O}_{2}}$ and using a conversion factor of 4.8 $\mathrm{kcal} / 1 \mathrm{O}_{2}$, we calculated the daily energy expenditure for a 15 -h rest ( 65 beats/min), 9-h active (90 beats/min) cycle for badgers during February 1978 as $322 \mathrm{kcal} /$ day. This increased to $480 \mathrm{kcal} /$ day in March with an 11-h activity period. Lampe (1976) calculated that, during the summer, the badger must detect, pursue, and consume 1.7 gophers $(418 \mathrm{kcal})$ each day in order to balance energy expenditures. Badgers during the 1977-1978 winter in Wyoming may have augmented their nutrient requirements through predatory activity. This is implied by the presence of daily foraging activity within the enclosures and by only moderate
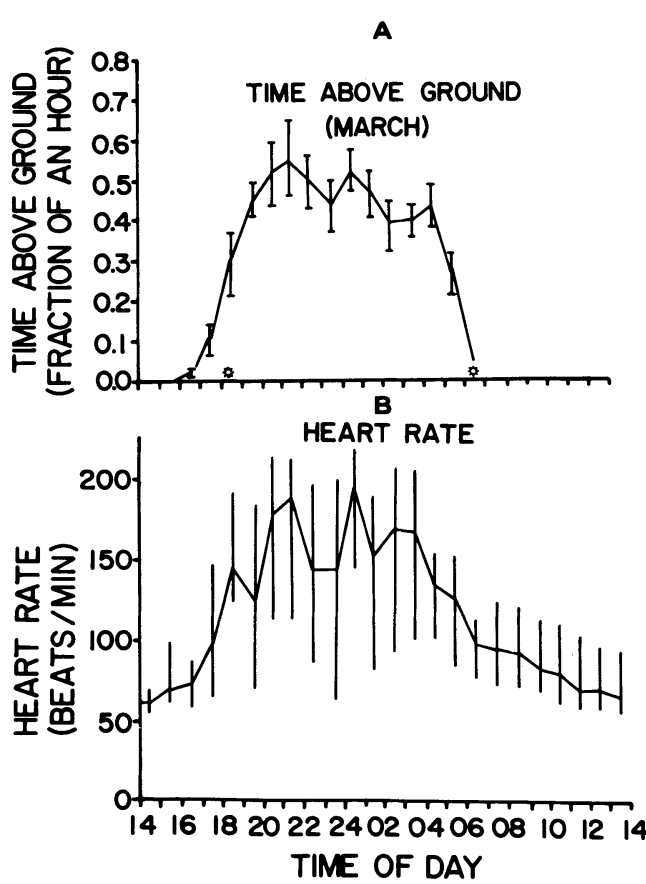

FIG. 9.-Changes in the time spent above ground $(A)$ and changes in heart rate $(B)$ by badgers during March 1978. Time spent above ground for four badgers is expressed in fractions of an hour and represents hourly values averaged for the month; brackets represent $\pm 1 \mathrm{SE}$. Symbols represent sunrise and sunset. Heart rate of two badgers is expressed as the monthly average over $1-\mathrm{h}$ periods; vertical lines represent the range. fat utilization, as indicated by carcass analysis of field animals. The more severe 1978-1979 winter, however, was associated with prolonged restriction below ground by badgers within the enclosures. These animals had a daily energy expenditure of $240 \mathrm{kcal}$, which is about $25 \%$ lower than that observed in February of the previous year and $13 \%$ below the BMR calculated in the laboratory.

In a study of the European badger, Johansson (1957) showed that many aspects of the animal's annual cycle are similar to those of hibernators. In addition, Slonin (1952) observed an instability of body temperature and metabolism in the European badger during winter similar to that observed in bears. More definitively, the

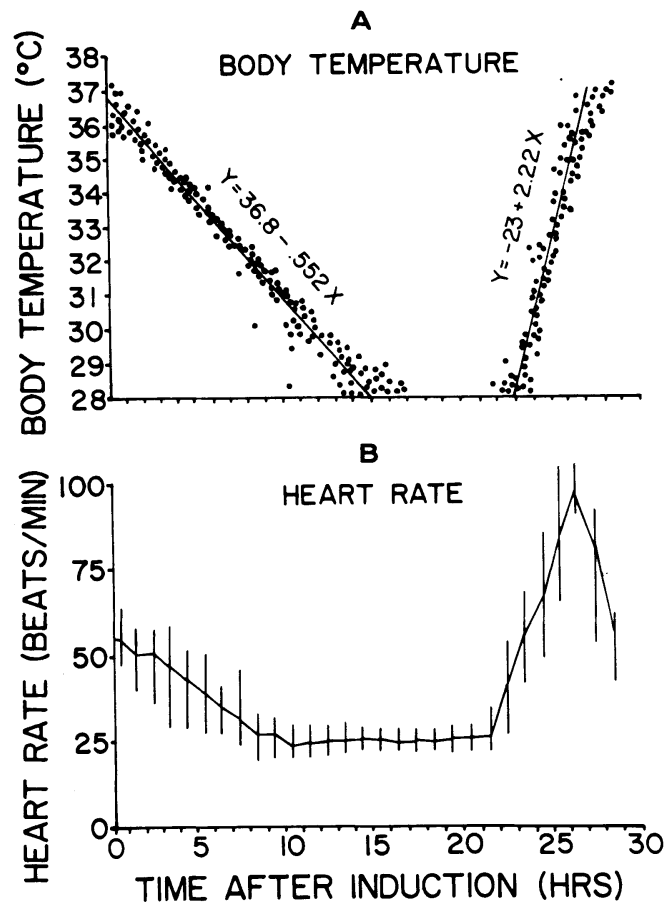

Fig. 10.-Body temperatures $(A)$ and average heart rate $(B)$ of a badger entering, within, and arousing from torpor during December and January 1978-1979. The lines depicting entrance to and arousal from torpor describe least-squares regressions of body temperatures. Heart rate is expressed as the average over 1-h periods; vertical lines represent the range. 
present study has demonstrated the ability of the American badger to enter a state of shallow torpor. Induction into torpor may be in response to cold temperatures and food deprivation. It appears that the badger utilizes its ability for short-term hypothermia only during the coldest months of winter. In addition, Harlow (1979a) showed that badgers fasted 30 days had a $22 \%$ reduction in basal metabolism. Therefore, both factors may be acting in concert to cause the badger to go hypothermic.

Body temperature and metabolism during the torpor cycle are close to predicted values. For example, Swan (1974) characterizes torpor by a reduction in metabolism along a temperature coefficient $\left(Q_{10}\right)$ slope of about 2.0. The badger had a $Q_{10}$ of 2.15 as its metabolism dropped from $0.26 \mathrm{~cm}^{3}$ / $\mathrm{g} \cdot \mathrm{h}$ at $37 \mathrm{C}$ to $0.13 \mathrm{~cm}^{3} / \mathrm{g} \cdot \mathrm{h}$ at $28 \mathrm{C}$. In addition, animals with $\mathrm{Q}_{10}$ values near 2.0 are characterized by a $7.18 \%$ drop in $\dot{\mathrm{V}}_{\mathrm{O}_{2}}$ per ${ }^{\circ} \mathrm{C}$ (Morrison 1960). From this relationship, the predicted $\dot{\mathrm{V}}_{\mathrm{O}}$, of a badger that dropped its body temperature $9 \mathrm{C}$ would be $0.130 \mathrm{~cm}^{3} / \mathrm{g} \cdot \mathrm{h}$, which closely approximates the $0.133 \mathrm{~cm}^{3} / \mathrm{g} \cdot \mathrm{h}$ calculated from heart rate while in torpor. Assuming a specific heat of tissue to be $0.82 \mathrm{kcal} / \mathrm{kg} /{ }^{\circ} \mathrm{C}$ (Hart 1951), it would require $59.8 \mathrm{kcal}$ to raise the temperature of an $8-\mathrm{kg}$ animal by $9 \mathrm{C}$. It required $60.2 \mathrm{kcal}$ to bring the badger's temperature from $28 \mathrm{C}$ to $37 \mathrm{C}$, very close to the predicted expenditure. However, the $4 \mathrm{~h}$ required for this arousal were $1.5 \mathrm{~h}$ longer than predicted by the formula: ${ }^{\circ} \mathrm{C} \min ^{-1}=2.03 S^{-0.04}$ (Bartholomew 1972). It has long been known that small heterothermic mammals warm up more rapidly than large ones. As a consequence, Pearson (1960) believes that large mammals cannot afford the time necessary to enter and emerge from torpidity each day. Torpor, however, was observed in the badger only during the cold months of December and January and did not occur every day. Periods of lowest body temperature varied in length from 6 to $18 \mathrm{~h}$ with an average 29 -h torpor cycle from entrance to the end of arousal. In addition, normothermic periods were not characterized by foraging activity but by states of rest or sleep. As a consequence, the time required for the badger to arouse is insignificant as long as the torpor cycle provides an energy saving. Energy expenditure during the 29-h torpor cycle required $220 \mathrm{kcal}$ for an 8 -kg animal. Entry into torpor accounted for $26 \%$ of the total energy spent in the torpor cycle, and torpor itself accounted for $31.5 \%$. The remaining $42.5 \%$ was used during arousal. If the badger slept continuously with a heart rate of 55 beats $/ \mathrm{min}$ for the same period, it would expend 300 $\mathrm{kcal}$. Therefore, torpor provided the badger a $27 \%$ energy savings or $8.5 \mathrm{~g}$ of fat during the period of an average cycle. This would amount to a total of $255 \mathrm{~g}$ of fat, which would allow the badger an extra 10 days of rest without food during early spring to act as a buffer against bad weather and food scarcity.

\section{LITERATURE CITED}

Bartholomew, G. A. 1972. Aspects of timing and periodicity of heterothermy. Pages 663-680 in F. W. South, J. P. Hannon, J. E. Willis, E. T. Pengelley, and N. R. Alpert, eds. Hibernation and hypothermia, perspectives and challenges. American Elsevier, New York. 743 pp.

BROCKE, R. H. 1970. The winter ecology and bioenergetics of the opposum Didelphis marsupialis, as distributional factors in Michigan. Ph.D. thesis. Michigan State University. 215 pp.

Cheatum, E. L. 1949. Bone marrow as an index of malnutrition in deer. New York State Conserv. 3(5) : 19-27.

Crow, D. M. 1972. The presence of annuli in bob- cat tooth cementum layers. J. Wildlife Manage. 36(4) : 1330-1332.

Depocas, F., and J. S. Hart. 1957. Use of the Pauling oxygen analyzer for measurement of oxygen consumption in open-circuit systems and in short-lag, closed-circuit apparatus. J. Appl. Physiol. 10:388-393.

Fisher, K. C., and J. F. MANERy. 1967. Water and electrolyte metabolism in heterotherms. Pages 235-279 in K. C. Fisher, A. R. DAwe, C. P. Lyman, E. Schonbaum, and F. E. South, eds. Mammalian hibernation. Bull. Mus. Comp. Zool. Harvard Coll. Oliver \& Boyd, Edinburgh and London. 534 pp. 
FolK, G. E. 1974. Introduction to environmental physiology. Lea \& Febinger, Philadelphia. $465 \mathrm{pp}$.

Franzmann, A. W., and P. D. Arneson. 1976. Marrow fat in Alaskan moose femurs in relation to mortality factors. J. Wildlife Manage. 40(2) :366-369.

Getringer, R. D. 1975. Metabolism and thermoregulation of a fossorial rodent, the northern pocket gopher (Thomomys talpoides). Physiol. Zool. 48(4):311-322.

HarLOW, H. J. 1979a. Behavioral and physiological adaptations by the American badger, Taxidea taxus, to food deprivation and cold. Ph.D. diss. University of Wyoming. 189 pp.

_ 1979b. A photocell monitor to measure winter activity of confined badgers. J. Wildlife Manage. 43(4):997-1001.

Harlow, H. J., R. W. Weeks, R. M. Long, and J. M. Schrib. 1979. Pages 14-20 in F. M. Long, ed. Heart rate and body temperature of free roaming badgers. International Conference on Wildlife Biotelemetry, Laramie, Wyo.

HarT, J. S. 1951. Calorimetric determination of average body temperature of small mammals and its variation with environmental conditions. Can. J. Zool. $29: 224-233$.

Herreid, C. F., and B. Kessel. 1967. Thermal conductance in birds and mammals. Comp. Biochem. Physiol. 21 :405-414.

Holter, J. B., W. E. Urban, H. H. Hayes, and H. Silver. 1976. Predicting metabolic rate from telemetered heart rate in white-tailed deer. J. Wildlife Manage. 40(4) :626-629.

Iverson, J. A. 1972. Basal energy metabolism of mustelids. J. Comp. Physiol. 81 :341-344.

Johansson, B. 1957. Some biochemical and electrocardiographic data on the badger. Acta Zool. 38: 205-218.

Johnson, S. F., and J. A. Gessaman. 1973. An evaluation of heart rate as an indirect monitor of free-living energy metabolism. Pages 44-54 in J. A. Gessaman, ed. Ecological energetics of homeotherms: a review compatible with ecological modeling. Utah State University Press, Logan.

KLEIBER, M. 1975. The fire of life: an introduction to animal energetics. Revised ed. Krieger, New York. 453 pp.

LAMPE, R. 1976. Aspects of the predatory strategy of the North American badger, Taxidea taxus.
Ph.D. diss. University of Minnesota at Minneapolis St. Paul. 103 pp.

MCNAB, B. K. 1966. The metabolism of fossorial rodents: a study of convergence. Ecology 47 : 712-733.

Morales, M. F., E. N. Rathbun, R. E. Smith, and N. PACE. 1945. Studies on body composition. 11: theoretical considerations regarding the major tissue components with suggestions for application to man. J. Biol. Chem. 158:667-684.

Morrison, P. 1960. Some interrelations between weight and hibernation function. Pages 75-90 in C. P. Lyman and A. R. Dawe, eds. Mammalian hibernation. Bull. Mus. Comp. Zool. Harvard Coll., vol. 124.

Mrosovsky, N. 1976. Lipid programmers and life strategies in hibernators. Amer. Zool. 16:685697.

Nelson, R. A. 1973. Winter sleep in the black bear. Mayo Clin. Proc. 48:733-737.

Neter, J., and W. Wasserman. 1974. Applied linear statistical models. Irwin, Homewood, Ill. $420 \mathrm{pp}$.

Pearson, O. P. 1960. Torpidity in birds. Pages 93-104 in C. P. Lyman and A. R. Dawe, eds. Mammalian hibernation. Bull. Mus. Comp. Zool. Harvard Coll. vol. 124.

Pruite, W. O. 1960. Animals in the snow. Sci. Amer. 202(1) :60-68.

SHIELD, J. 1972. Acclimation and energy metabolism of the dingo, Canis dingo, and the coyote, Canis latrans. J. Zool. (London) 168:483-501.

SLonin, A. D. 1952. Animal heat and its regulation in the mammalian organism. Academy of Science, USSR, Leningrad and Moscow. 327 pp.

Stephen, A. B. 1969. Temperature within a beaver lodge in winter. J. Mammal. 50(1) : 124-136.

Swan, H. 1974. Thermoregulation and bioenergetics. American Elsevier, New York. 430 pp.

Vose, R. N., and D. G. DunlaP. 1968. Wind as a factor in the local distribution of small mammals. Ecology 49(3) :381-386.

Weeks, D., F. Long, J. M. Schrib, D. Stephens, and H. HarLow. 1978. A fully implantable three channel, very low frequency telemetry system. Proc. Annu. Conf. Eng. Med. Biophys. 20:129.

WELCH, W. R. 1978. Fitting segmented straight lines. Univ. Wisconsin, Lab. Biophys. Ecol. Tech. Rep. 2. 15 pp. 